\title{
Effects of nitrogen deposition and climate change on nitro- gen runoff at Norwegian boreal forest catchments: the MERLIN model applied to Risdalsheia (RAIN and CLIMEX projects)
}

\author{
Richard F. Wright, ${ }^{1}$ Claus Beier ${ }^{2}$ and Bernard J. Cosby ${ }^{3}$ \\ ${ }^{1}$ Norwegian Institute for Water Research, Box 173 Kjelsås, N-0411 Oslo, Norway \\ 2 RISØ National Laboratory, Plant Biology and Biogeochemistry Departments, Box 49, DK-4000 Roskilde, Denmark \\ 3 Department of Environmental Sciences, University of Virginia, Charlottesville, VA 22903, USA
}

\section{Abstract}

The catchment-scale experiments of the RAIN and CLIMEX projects conducted on boreal forest ecosystems at Risdalsheia, southernmost Norway, provide a unique set of data on the flux of nitrogen $(\mathrm{N}$ ) in runoff following changes in $\mathrm{N}$ deposition, carbon dioxide $\left(\mathrm{CO}_{2}\right)$ level and temperature. MERLIN (Model of Ecosystem Retention and Loss of Inorganic Nitrogen), a recentlydeveloped model that focuses on $\mathrm{N}$ leaching, provides a means by which these data can be placed into a quantitative framework.

The features of the $\mathrm{N}$ flux in runoff at Risdalsheia to be explained include (1) leaching of about $30-50 \mathrm{mmol} \mathrm{m}^{-2} \mathrm{yr}^{-1}(30-40 \%$ of $\mathrm{N}$ deposition) during the period 1985-1997 at reference catchments, (2) rapid and dramatic reduction in $\mathrm{N}$ leaching following experimental reduction in $\mathrm{N}$ deposition in 1985 at KIM catchment, (3) increased flux of about $5 \mathrm{mmol} \mathrm{m}^{-2} \mathrm{yr}^{-1}$ following onset of $3-5^{\circ} \mathrm{C}$ warming and increased $\mathrm{CO}_{2}$ in 1995 at $\mathrm{KIM}$ catchment, and (4) increased flux of about $12 \mathrm{mmol} \mathrm{m}^{-2} \mathrm{yr}^{-1}$ following $3-5^{\circ} \mathrm{C}$ warming of soil in 1995 at EGIL catchment.

One set of calibrated model parameters is sufficient to simulate the changes in $\mathrm{N}$ runoff at both experimental catchments for both of the manipulations. The model supports the conceptual picture of the soil as the major sink for $\mathrm{N}$ inputs from deposition with $\mathrm{N}$ accumulating in both the forest floor (labile organic matter LOM) and the bulk soil (refractory organic matter ROM). As the molar carbon/nitrogen $(\mathrm{C} / \mathrm{N})$ ratio of LOM decreases to below 23, progressively less $\mathrm{N}$ is immobilised and more goes to runoff. The model also supports the conceptual picture of increased rate of decomposition of old soil organic matter in response to higher temperature. An increase of $5 \%$ is sufficient to produce the $5-12 \mathrm{mmol} \mathrm{m}^{-2} \mathrm{yr}^{-1}$ increase in $\mathrm{N}$ flux in runoff observed at the 2 experimental catchments. The MERLIN simulations are consistent with measurements of increase in net mineralisation rates (per catchment area by $70 \mathrm{mmol} \mathrm{m}^{-2} \mathrm{yr}^{-1}$ ) and $\mathrm{N}$ contents in foliage in treated and reference areas before and after onset of treatment.

Runoff provides a very sensitive indicator of changes in $\mathrm{N}$ cycling within the ecosystem. Small changes in key processes such as $\mathrm{N}$ mineralisation give rise to large relative changes in $\mathrm{N}$ flux. Uncertainties in measurements are generally much larger than changes indicated by the model calibration.

\section{Introduction}

Boreal ecosystems contain large stores of carbon (C) and nitrogen $(\mathrm{N})$ and currently provide a major global sink for atmospheric carbon dioxide $\left(\mathrm{CO}_{2}\right)$ (Kirschbaum and Fischlin, 1995). Primary productivity in boreal ecosystems is typically $\mathrm{N}$ limited, and chronic $\mathrm{N}$ deposition has promoted forest growth in large regions of northern Europe and eastern North America (Kauppi et al., 1992; Schindler and Bayley, 1993). $\mathrm{N}$ deposition can, however, move $\mathrm{N}-$ limited ecosystems towards $\mathrm{N}$-saturation, as manifest by increased leaching of inorganic $\mathrm{N}$ from beneath the root- ing zone (Aber et al., 1989; Gundersen, 1995). Increased flux of nitrate leads to acidification of sensitive surface waters (Henriksen and Brakke, 1988) and adds to $\mathrm{N}$ loading in coastal marine waters (Fischer and Oppenheimer, 1991; Lajtha et al., 1995).

Future global changes such as increased atmospheric $\mathrm{CO}_{2}$ levels and higher temperatures will affect the cycling of $\mathrm{C}$ and $\mathrm{N}$ in boreal ecosystems (Kirschbaum, 1995). More $\mathrm{CO}_{2}$ and warmer climate should promote primary productivity and, thus, enhance the sink for $\mathrm{CO}_{2}$ if $\mathrm{N}$ is in sufficient supply. Higher soil temperature should 

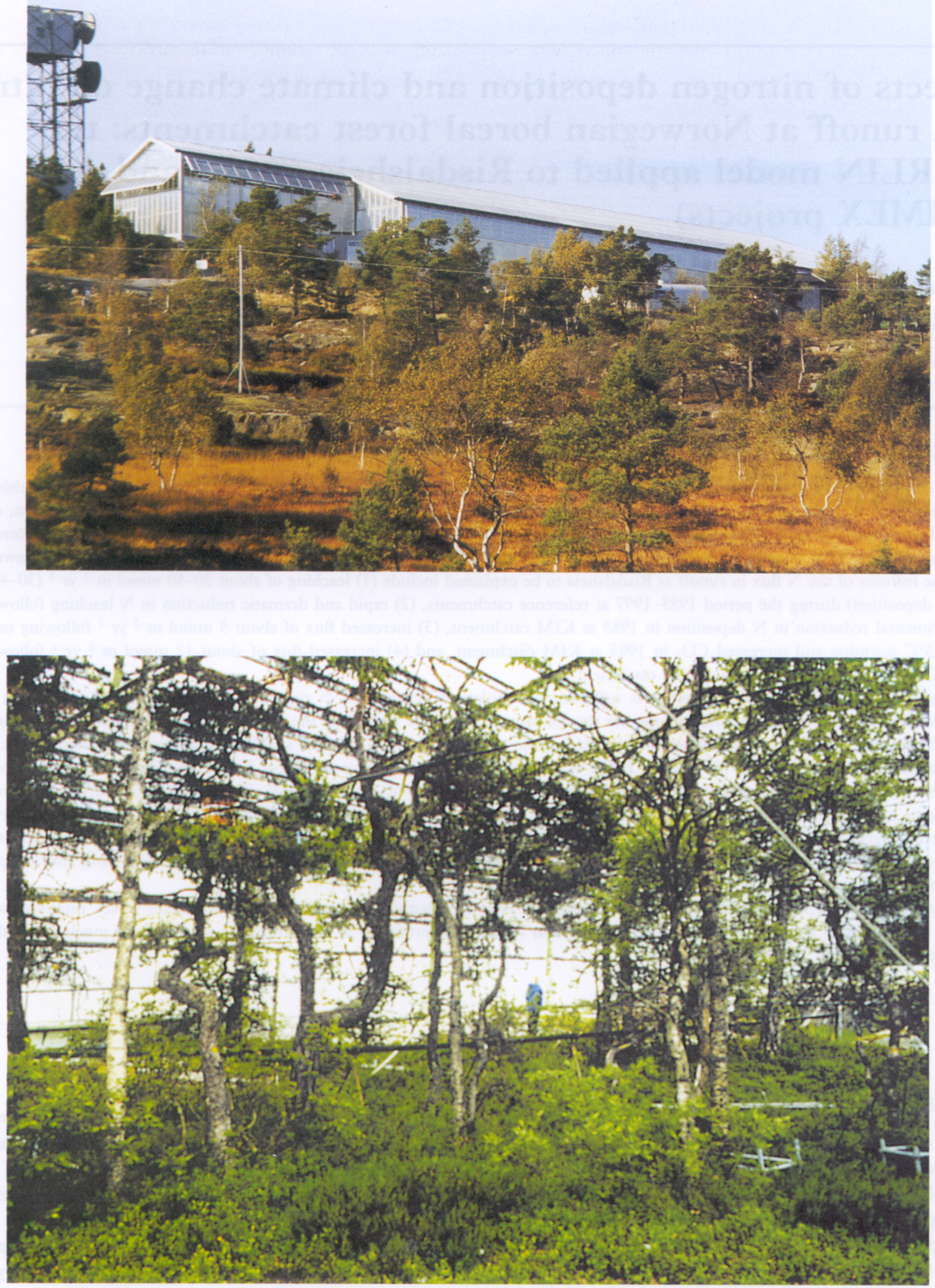

Fig. 1. Photos of the 1200- $m^{2}$ enclosure covering KIM catchment of the CLIMEX project at Risdalsheia, southernmost Normay. 
increase mineralisation of soil organic matter, thus releasing stored $\mathrm{N}$ that then can go to plant growth and possibly also to leachate and runoff. But mineralisation also releases stored soil $\mathrm{C}$ as $\mathrm{CO}_{2}$ to the atmosphere. The net result of global change could, thus, be either an increase or decrease in $\mathrm{CO}_{2}$ sequestration by boreal ecosystems and, in regions subject to $\mathrm{N}$ deposition, an increase or decrease in $\mathrm{N}$ leached to surface waters. Uncertainly in the direction and magnitude of ecosystem response is a major limitation in use of models to extrapolate in space and time (Kirschbaum, 1993; Rastetter et al., 1991; Melillo et al., 1993).

The catchment-scale experiments of the RAIN (Wright et al., 1993) and CLIMEX projects (Van Breemen et al., 1998; Wright, 1998) conducted on boreal forest ecosystems at Risdalsheia, southernmost Norway, comprise a unique series of experiments at the ecosystem scale on the effects and interactions of $\mathrm{N}$ deposition and increased temperature and $\mathrm{CO}_{2}$ on $\mathrm{C}$ and $\mathrm{N}$ cycling and especially the runoff chemistry (Figs. 1 and 2). Runoff chemistry is of particular interest, since it provides a sensitive integrated signal of change in terrestrial catchments; whereas small changes in the internal $\mathrm{N}$ cycle are often difficult to measure directly due to spatial heterogeneity and temporal variations, the net result is often a significant change in $\mathrm{N}$ flux in runoff. The results of the long-term experiments at Risdalsheia follow the effects through to changes in runoff chemistry, and thus provide information on the wholeecosystem response.

These data provide a robust test of process-oriented models used to simulate ecosystem response to changes in $\mathrm{N}$ deposition, $\mathrm{CO}_{2}$ and climate. MERLIN (Model of Ecosystem Retention and Loss of Inorganic Nitrogen), a recently-developed model that focuses on $\mathrm{N}$ leaching (Cosby et al., 1997), provides a means by which the data from the RAIN and CLIMEX experiments can be placed into a quantitative framework, and the responses to environmental changes evaluated. MERLIN has been applied previously to the NITREX project sites at Aber, Wales, UK (Emmett et al., 1997) and at Gårdsjön, Sweden (Kjonaas et al., 1997) to simulate changes in $\mathrm{N}$ runoff following experimental change in $\mathrm{N}$ deposition. This paper describes an evaluation of MERLIN as a tool for simulation of changes in $\mathrm{N}$ leaching in response to changes in $\mathrm{N}$ deposition, in $\mathrm{CO}_{2}$ and in temperature using the 14 year record from Risdalsheia.

\section{Methods}

\section{DESCRIPTION OF MERLIN}

MERLIN is a simple process-oriented model focused on simulation and prediction of concentrations of inorganic nitrogen in soil leachate and runoff in terrestrial ecosystems (Cosby et al., 1997). The model links the $\mathrm{C}$ and $\mathrm{N}$ cycles. The ecosystem is simplified to one plant compart- ment (active biomass such as foliage and roots) and two soil compartments (labile and refractory organic matter) (Fig. 3). Inactive biomass such as boles, large branches and large roots are assumed not to participate in the $\mathrm{N}$ and $\mathrm{C}$ cycling, and are denoted 'long-term storage' in the model. The $\mathrm{C}$ pools and fluxes are set external to the model. $\mathrm{N}$ pools and fluxes are then linked to $\mathrm{C}$ by $\mathrm{C} / \mathrm{N}$ ratios in the pools. Transfer between compartments occurs by processes such as plant uptake, litterfall, immobilisation, mineralisation, nitrification and denitrification. There is no feedback between $\mathrm{N}$ status and $\mathrm{C}$ fluxes; this would be the next step in complexity. Thus, $\mathrm{N}$ availability does not feed back to change net primary productivity in the model. The key to MERLIN is that the rates of these processes are assumed to be governed by $\mathrm{C} / \mathrm{N}$ ratios in the various pools. MERLIN is comprised of (1) a book-keeping procedure in which inputs and outputs of $\mathrm{C}$ and $\mathrm{N}$ to the ecosystem and between the four compartments are tallied, and (2) a series of simultaneously-operating processes that describe the transfer of $\mathrm{C}$ and $\mathrm{N}$ between the compartments and out of the ecosystem. The model is designed to function at annual time steps.

\section{SITE DESCRIPTION}

Risdalsheia is located near Grimstad, Norway, $\left(58^{\circ} 23^{\prime} \mathrm{N}\right.$, $8^{\circ} 19^{\prime} \mathrm{E}$ ) about $20 \mathrm{~km}$ inland from the North Sea. The site is $300 \mathrm{~m}$ a.s.l., and is typical of large areas of upland southern Norway. Risdalsheia has a maritime climate with mean annual precipitation of about $1400 \mathrm{~mm}$, runoff $1200 \mathrm{~mm}$, and mean annual temperature of about $5^{\circ} \mathrm{C}$ (mean of $-3^{\circ} \mathrm{C}$ in January and $+16^{\circ} \mathrm{C}$ in July). Vegetation is mainly a sparse cover of pine (Pinus sylvestris L.) and birch (Betula pubescens $\mathrm{L}$.) with heather (Calluna vulgaris L.) and blueberry (Vaccinium myrtillus L.) as dominant ground species. Bedrock is biotite granite covered by thin (about $10 \mathrm{~cm}$ ) and patchy podsolic and peaty soils.

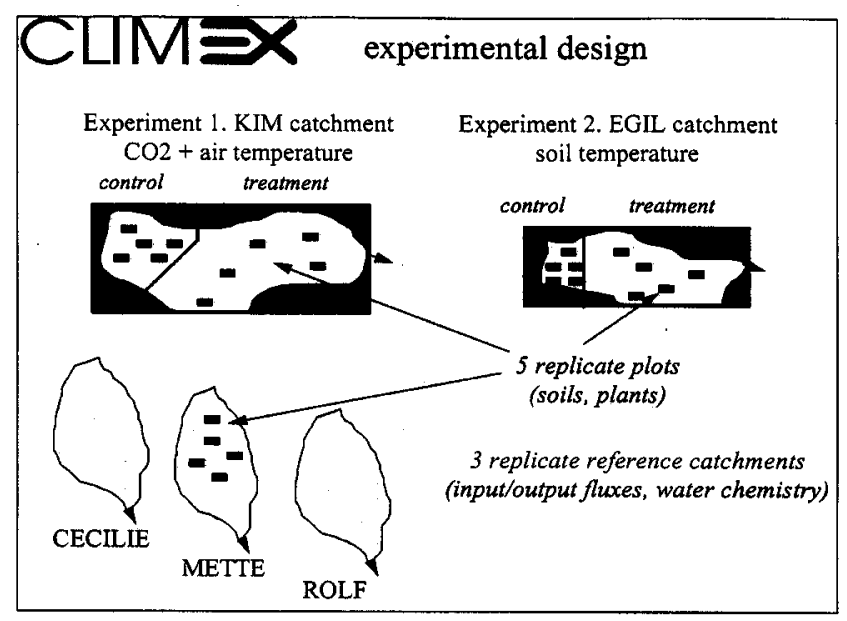

Fig. 2. Experimental design of CLIMEX. 


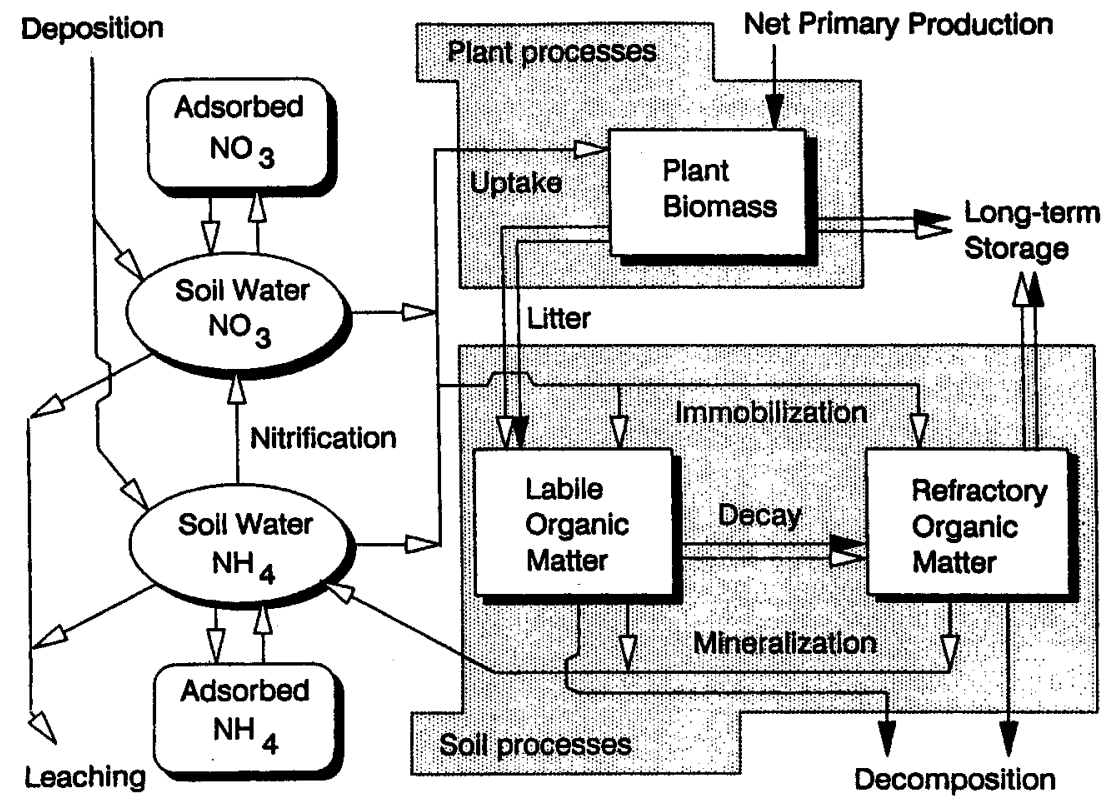

Fig. 3. A schematic representation of the MERLIN model. Closed arroms represent fluxes of inorganic $C$; open arrows represent fuxes of inorganic $N$. Paired closed/open arroms represent fluxes of organic material containing both $C$ and $N$ (from Cosby et al., 1997$)$.

Risdalsheia receives high levels of acid deposition. Mean values of total deposition (wet and dry) for the 8-year period 1984-92 were $226 \mathrm{mmol} \mathrm{m}^{-2} \mathrm{yr}^{-1} \mathrm{~S}, 132 \mathrm{mmol} \mathrm{m}^{-2}$ $\mathrm{yr}^{-1} \mathrm{~N}\left(59\right.$ as $\mathrm{NH}_{4}{ }^{+}$and 73 as $\mathrm{NO}_{3}{ }^{-}$), and $106 \mathrm{mmol} \mathrm{m}^{-2}$ $\mathrm{yr}^{-1} \mathrm{H}^{+}$(Wright et al., 1993).

\section{RAIN AND CLIMEX EXPERIMENTS}

The first set of experiments (the RAIN project; Reversing Acidification In Norway) involved exclusion of ambient $\mathbf{N}$ and sulphur (S) deposition. These experiments comprise three headwater catchments of which KIM catchment $(860$ $\mathrm{m}^{2}$ ) is covered by roof above the canopy and received clean rain, EGIL catchment $\left(400 \mathrm{~m}^{2}\right)$ is covered by roof and received recycled ambient acid rain, and ROLF catchment $\left(220 \mathrm{~m}^{2}\right)$ serves as untreated reference (Wright et al., 1993) (Table 1). Manipulation of the precipitation (termed 'clean' precipitation) at KIM catchment began June 1984 and has continued uninterrupted through 1997. Incoming precipitation is collected from the roofs by gutters, led to storage tanks, filtered, passed through a mixed-bed ionexchange resin, dosed with natural levels of sea salts (at about 1:8000 during the summer and 1:5000 during the winter) and automatically distributed back out under the roofs through a sprinkler system at $2 \mathrm{~mm} \mathrm{hr}^{-1}$ maximum rate. During the winters of 1984-85 through 1988-89, the sprinkling systems at KIM and EGIL catchments were not operated. Snow was made artificially using commercial snow-making equipment. Water from a nearby lake was ion-exchanged and sea salts readded. Since 1989, the sprinkling system has been operated all winter, and snowfall outside is compensated by extra watering with ion- exchanged lakewater during mild periods. At all times, care is taken to avoid disturbance of the vegetation and soils within the catchments.

The second set of experiments (the CLIMEX project; Climate change experiment) began on April 1994 and involves manipulation with $\mathrm{CO}_{2}$ and air temperature (KIM catchment) and soil warming (EGIL catchment). These new treatments (Dise and Jenkins, 1993) are superimposed on the ongoing RAIN treatments. In the winter of 1993-94, KIM catchment was enclosed completely with air-tight transparent walls (Fig. 1). An air-tight transparent dividing wall was installed across the catchment such that the uppermost $20 \%$ of the catchment (termed control KIM-c) receives the clean rain treatment only and not higher $\mathrm{CO}_{2}$ and temperature (Fig. 2). KIM-c serves as control area for plant and soil studies which are conducted on small plots of about $4 \mathrm{~m}^{2}$. Runoff from KIM-c is sampled weekly for chemical composition; it flows into the treated $80 \%$, and thus runoff from the treated section (KIM-t) contains water from both KIM-c and KIM-t.

In the treatment section (KIM-t), $\mathrm{CO}_{2}$ is added to the air during the growing season (defined as 1 April-31 October) at target concentration of $560 \mathrm{ppmv}$. The air is warmed by an electric central heating system in which heated fluid (maximum $60^{\circ} \mathrm{C}$ ) circulates through 3 ranks of 6-cm diameter steel pipes mounted on the insides of the walls. The target for air warming is $+5^{\circ} \mathrm{C}$ above KIM-c in January and $+3^{\circ} \mathrm{C}$ in July with intermediate temperatures in the intervening months. Added precipitation is not warmed; it comprises a negligible heat sink. Average air temperature rise achieved during the first 3 years of treatment was $3.7^{\circ} \mathrm{C}$ (Table 2). 
Table 1. Overviem of the 5 catchments at Risdalsheia included in the CLIMEX project. The first three mere run by the RAIN project for 11 years (7une 1983-May 1994). Clean rain treatment began in fune 1984. CLIMEX treatment began in April 1994. KIM and EGIL were divided in April 1994 to an upper control section (KIM-c,EGIL-c, no climate change) and lower treatment section (KIM-t, EGIL-t, climate change).

\begin{tabular}{lcllll}
\hline catchment & area m-2 & enclosure & rain treatment & climate treatment & monitor start \\
\hline KIM & 860 & roof & clean & $\mathrm{CO}_{2}$ +air warming & March 1984 \\
EGIL & 400 & roof & ambient, acid & soil warming & March 1984 \\
ROLF & 220 & no roof & ambient, acid & none & October 1984 \\
METTE & 650 & no roof & ambient, acid & none & May 1993 \\
CECILIE & 380 & no roof & ambient, acid & none & May 1993 \\
\hline
\end{tabular}

Table 2. Mean annual temperature $(C)$ in air at KIM catchment (control and treatment sections) and in soil at $5 \mathrm{~cm}$ depth at EGIL catchment (control and treatment sections) for 2 years prior to onset (1993-94) and 3 years of CLIMEX treatment (1995-97). The year goes from April the previous year to the following March.

\begin{tabular}{lcccccc}
\hline Year & \multicolumn{2}{c}{ KIM air temperature ${ }^{\circ} \mathrm{C}$} & \multicolumn{3}{c}{ EGIL soil temperature ${ }^{\circ} \mathrm{C}$} \\
treatment & control & delta & control & deatment & delta \\
\hline 1993 & 6.3 & & & 7.0 & & \\
1994 & 4.6 & & & 7.3 & & \\
1995 & 6.9 & 10.0 & 3.1 & 6.8 & 9.4 & 2.6 \\
1996 & 5.6 & 9.5 & 4.9 & 7.0 & 10.2 & 3.2 \\
1997 & 6.6 & 10.9 & 3.3 & 6.8 & 10.9 & 4.1 \\
mean $1995-97$ & 6.4 & 10.1 & 3.7 & 6.9 & 10.2 & 3.3 \\
\hline
\end{tabular}

At EGIL catchment, soil warming is accomplished by electric heating cables placed approximately $10 \mathrm{~cm}$ apart on the soil surface beneath the litter in the lower $80 \%$ (treatment) part of EGIL catchment. The upper $20 \%$ of the catchment serves as unheated control for plant growth, soil, soil solution and mineralisation measurements. Temperatures are monitored by a network of 120 thermistors placed throughout the control and the heated areas at 6 levels ( 25 and $10 \mathrm{~cm}$ above soil, and $0,5,15$ and $30 \mathrm{~cm}$ in the soil). The set-up aimed at a similar temperature target as for KIM-t and maintains a seasonally-varying temperature difference between the control and heated areas of $5^{\circ} \mathrm{C}$ in January and $3^{\circ} \mathrm{C}$ in July. The heating cables increase the soil temperature at all depths but not the overlying air (Lükewille et al., 1995; Lükewille and Wright, 1997). During the first 3 years of treatment, average soil temperature rise at $5 \mathrm{~cm}$ depth was $3.3^{\circ} \mathrm{C}$ (Table 2).

As part of the CLIMEX project, two additional untreated reference catchments (METTE, CECILIE) were included beginning in May 1993 (Table 1).

\section{PRECIPITATION AND RUNOFF}

Ambient bulk precipitation is collected by funnel and volume measured weekly at the meteorological station located in an open area at Risdalsheia. At KIM and EGIL catch- ments, the volume of sprinkled water is metered and read at minimum weekly intervals.

Chemical composition of ambient bulk precipitation is determined on samples collected weekly and refrigerated pending analysis. Samples are analysed for $\mathrm{pH}$, electrical conductance, calcium $(\mathrm{Ca})$, magnesium $(\mathrm{Mg})$, sodium $(\mathrm{Na})$, potassium $(\mathrm{K})$, ammonium $\left(\mathrm{NH}_{4}\right)$, nitrate $\left(\mathrm{NO}_{3}\right)$, chloride $(\mathrm{Cl})$ and sulphate $\left(\mathrm{SO}_{4}\right)$.

Dry deposition of $\mathrm{S}$ and $\mathrm{N}$ is estimated from measured daily concentrations for $S$ and $N$ species in air at the nearby EMEP station at Birkenes and assumed deposition velocities. Dry deposition at EGIL catchment is probably not reduced significantly by the roof, as the structure has no walls. Dry deposition of sea salts is estimated from the mass balance for $\mathrm{Cl}$ (Wright et al., 1993).

Rates of historic nitrogen deposition used for the period prior to start of measurements are based on estimates for emissions of nitrogen oxides $\left(\mathrm{NO}_{\mathrm{x}}\right)$ in Europe (Simpson et al., 1997) (Fig. 4). Since 1983, deposition has been measured on site for each of the treatments.

Runoff from the catchments is collected at fibreglass dams at the bottom of each catchment, led by hose to $0.5 \mathrm{~m}^{3}$ tanks which empty automatically when full. Discharge is measured by logging the number of tanks emptied. Samples for chemical analysis are collected automatically at about weekly intervals from each full tank (or 


\section{Risdalsheia N flux}

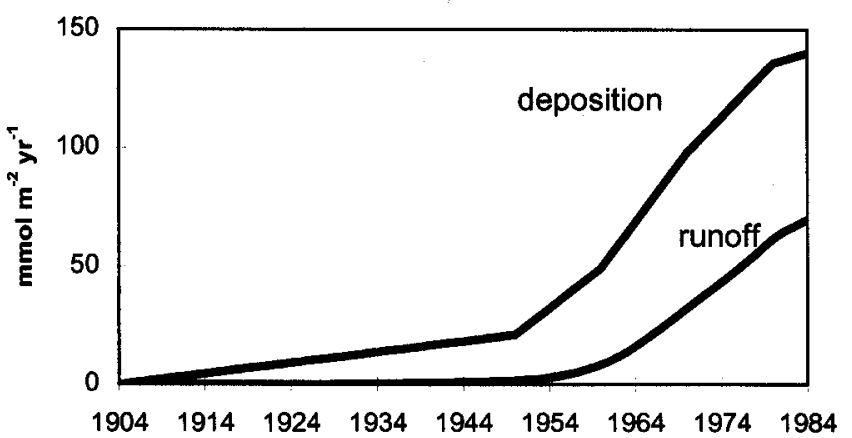

Fig. 4. Deposition of inorganic nitrogen (met and dry, sum of oxidised and reduced forms) estimated for the period 1900 to 1983 and scaled to measurements on site in 1984, and fux of inorganic $N$ in runoff simulated by MERLIN calibrated to match the measured level in 1984 at untreated reference catchments. Historical deposition estimates from Simpson et al. (1997); deposition and runoff measurements from Wright et al. (1993).

a pre-set selection of tanks). These systems at Risdalsheia have been in continuous operation since March 1984 (KIM, EGIL), October 1984 (ROLF) and May 1993 (METTE and CECILIE). Runoff samples are analysed for $\mathrm{pH}$, electrical conductance, $\mathrm{Ca}, \mathrm{Mg}, \mathrm{Na}, \mathrm{K}, \mathrm{NH}_{4}, \mathrm{NO}_{3}$, $\mathrm{Cl}, \mathrm{SO}_{4}$, aluminium species (reactive- $\mathrm{Al}$ and organic-Al), total organic $\mathrm{C}$ (TOC), total $\mathrm{N}$, total phosphorus (P), silica and fluoride. Organic $\mathrm{N}$ is defined as the molar difference of total $\mathrm{N}$ minus $\mathrm{NO}_{3}$ minus $\mathrm{NH}_{4}$ (Wright, 1998).

\section{TOTAL PLANT POOLS OF C AND N}

Estimates of the biomass pools of $\mathrm{C}$ and $\mathrm{N}$ in the trees are based on diameter at breast height (DBH) measured on all trees each year in October-November, on $\mathrm{C}$ and $\mathrm{N}$ concentrations in the various tree pools and on empirical relationships between pool sizes and DBH. C and $\mathrm{N}$ pool sizes were measured on six pine trees and six birch trees cut nearby but outside the experimental catchments. Each tree was separated into the sub-pools: stem wood; bark; large branches; small branches; foliage; and roots; and the biomass of each sub-pool was measured.

The pools of $\mathrm{C}$ and $\mathrm{N}$ in the ground vegetation are estimated from measurements at a Scots pine ecosystem in Sweden with average total aboveground biomass of $360 \mathrm{~g}$ $\mathrm{dw} \mathrm{m}^{-2}$ (Persson, 1980). At Risdalsheia, only $50 \%$ of the area is covered by ground vegetation giving a total of 180 $\mathrm{g} \mathrm{dw} \mathrm{m}^{-2}$. Below ground biomass is assumed equal to above ground biomass.

$\mathrm{C}$ and $\mathrm{N}$ pools are separated into the biologically active and inactive (storage) pools. The biologically active plant part is taken as needles, fine roots and $1 / 3$ of the branches, while stems, bark, large roots, and $2 / 3$ of the branches are defined as inactive. For the ground vegetation, the turnover time of the shrubs is so short that all ground vegetation can be considered to be biologically active. Prior to treatment in 1984, the vegetation is assumed to be at steady state with no net change in active or inactive biomass over time. The site is unproductive, and no major biomass removal or disturbances have occurred during the past few decades.

\section{LITTERFALL}

Transfer of $\mathrm{C}$ and $\mathrm{N}$ from the active plant pool to the soil pools by litterfall is estimated from litterfall measurements and estimates. Above ground litterfall was collected monthly in 10 samplers (28-cm diameter) in each plot. Below ground litterfall from roots was estimated from fine-root turnover which was assumed to be $100 \%$ per year.

\section{SOIL ORGANIC MATTER}

The total $\mathrm{C}$ and $\mathrm{N}$ pools in the soil are estimated from measurements of $\mathrm{C}$ and $\mathrm{N}$ content in bulk soil, $13.5 \%$ and $0.65 \%$, respectively, bulk density of the soil $\left(0.66 \mathrm{~g} \mathrm{~cm}^{-3}\right)$ and an average soil depth of $10 \mathrm{~cm}$ (Wright et al., 1993). These values are used for all catchments. In the MERLIN model, soil organic matter is represented by a recalcitrant (refractory) fraction (denoted ROM) which has a slow decomposition rate and a more labile and easilydecomposable fraction (denoted LOM). The partitioning into these two fractions is based on the observation that fresh litter decomposes by about $50 \%$ within the first year after litterfall (Verburg and van Breemen, (in press)). If it is assumed that the part of the litter material remaining after 5 years belongs to the ROM pool, the LOM pool will be in the order of 2 years of litterfall which amounts to about $6 \%$ of the $\mathrm{C}$ in the soil. Finally, the total amount of organic matter in both LOM and ROM is assumed to be constant during the period prior to onset of the CLIMEX treatments in 1994.

\section{DECOMPOSITION OF SOIL ORGANIC MATTER}

The assumption that there is no change in the plant, LOM and ROM C pools means that the total annual decomposition of organic matter in the soil plus the annual loss of organic $\mathrm{C}$ in runoff must equal the yearly litterfall. Total decomposition was separated into LOM and ROM. The net mineralisation of nitrogen needed to supply the plant uptake is assumed to originate $75 \%$ from LOM decomposition and $25 \%$ from ROM decomposition. The partitioning of the gross decomposition of organic matter between the LOM and ROM pools is set such that the pools were stable in the absence of $\mathrm{N}$ deposition or climate change (period 1904-34). This gave a ratio of gross-to-net $\mathrm{N}$ mineralisation of 2.55 for LOM and 1.00 for ROM. 


\section{AND N CYCLES}

Together, this information is used to construct generic ecosystem $\mathrm{C}$ and $\mathrm{N}$ cycles for the year 1994 for the untreated reference catchments at Risdalsheia ( Fig. 5). Denitrification and $\mathrm{N}$ fixation are assumed negligible.

\section{OBSERVED CHANGES IN N POOLS AND FLUXES}

The combination of (i) 14-year record of fluxes of $\mathrm{N}$ in runoff at the untreated reference catchments, (ii) the observed response in experimentally-changed $\mathrm{N}$ deposition at KIM catchment, and (iii) the subsequent response to superimposed changes in soil temperature at EGIL catchment and $\mathrm{CO}_{2}$ and air temperature at KIM catchment provide a very strict set of conditions to which the MERLIN model can be calibrated and tested. The observed changes in runoff $\mathrm{N}$ flux to be explained by the model include:

1. In 1984, at the start of measurements at Risdalsheia, runoff from all catchments contained high concentrations of both $\mathrm{NH}_{4}$ and $\mathrm{NO}_{3}$ with $\mathrm{N}$ flux in runoff about $30-40 \%$ of $\mathrm{N}$ flux in deposition.

2. During 11 years of measurements at EGIL catchment (roof, ambient acid rain), annual deposition and runoff of $\mathrm{N}$ varied from year-to-year by about a factor of 2 but there was no time trend. This holds also for ROLF catchment (untreated reference).

3. During the 11 years of the RAIN experiment at KIM catchment (roof, clean rain), the $90 \%$ reduction of $\mathrm{N}$ deposition caused an immediate and persistent reduction in $\mathrm{N}$ flux in runoff (Wright $e t$ al., 1993).

Table 3. Measured or estimated soil parameters, $C$ and $N$ pools (mol $\left.m^{-2}\right)$ and fluxes $\left(m o l ~ m^{-2} y r^{-1}\right)$ at Risdalsheia used for calibration of MERLIN to the untreated reference catchment for year 1984.

\begin{tabular}{|c|c|c|c|c|c|}
\hline \multicolumn{4}{|l|}{ Soil parameters } & \multicolumn{2}{|r|}{ Reference } \\
\hline mean depth (m) & 0.10 & & & measured & Wright et al. 1993 \\
\hline porosity (fraction) & 0.56 & & & measured & Wright et al. 1993 \\
\hline bulk density $\left(\mathrm{kg} \mathrm{m}^{-3}\right)$ & 660 & & & measured & Wright et al. 1993 \\
\hline Water fluxes (ambient 1985-97) & & &  & & \\
\hline annual precipitation (m) & 1.336 & & & measured & Wright 1998 \\
\hline annual runoff $(\mathrm{m})$ & 1.153 & & & measured & Wright 1998 \\
\hline $\mathrm{C}$ and $\mathrm{N}$ pools and fluxes & $\mathrm{C}$ & $\mathrm{N}$ & $\mathrm{C} / \mathrm{N}$ & & \\
\hline \multicolumn{6}{|l|}{ Deposition inorg. N (ambient 1986-88) } \\
\hline 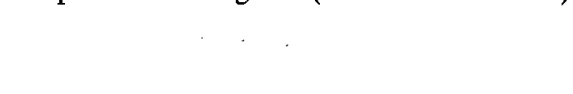 & \multicolumn{3}{|c|}{0.140} & measured & $\begin{array}{l}\text { Wright et al. 1993, Wright, } \\
1998\end{array}$ \\
\hline Runoff inorg. N (ambient 1986-88) & \multicolumn{3}{|c|}{0.043} & measured & $\begin{array}{l}\text { Wright et al. 1993, Wright, } \\
1998\end{array}$ \\
\hline Plant--active & 49 & 1.1 & 45 & measured & this study \\
\hline Plant-storage & 169 & 0.69 & 245 & measured & this study \\
\hline Litterfall & 21.55 & 0.48 & 45 & estimated & this study \\
\hline Plant-pool change & 0 & 0 & & assumed & . \\
\hline Soil Organic Matter-total & 743 & 35.4 & 21 & measured & Wright et al. 1993 \\
\hline Soil Organic Matter-LOM & 45 & 2.1 & 21 & estimated & \\
\hline Soil Organic Matter-ROM & 698 & 32.9 & 21 & estimated & \\
\hline Soil Organic Matter-pool change & 0 & 0 & & assumed & \\
\hline Total LOM and ROM decomposition & 20.75 & 0.98 & 21 & calculated & \\
\hline LOM decomposition-gross & 18.00 & 0.85 & 21 & calibrated & \\
\hline ROM decomposition-gross & 2.74 & 0.13 & 21 & calibrated & \\
\hline LOM decomposition-net & & 0.32 & & assumed & \\
\hline ROM decomposition-net & & 0.08 & & assumed & \\
\hline Net mineralisation & & $0.08-0$ & .20 & measured & $\begin{array}{l}\text { Verburg and Van Breemen, } \\
\text { in review, Verburg et al., in } \\
\text { review }\end{array}$ \\
\hline TOC/TON export & 0.81 & 0.02 & 41 & measured & Wright, 1998 \\
\hline
\end{tabular}




\section{N budgets KIM catchment}
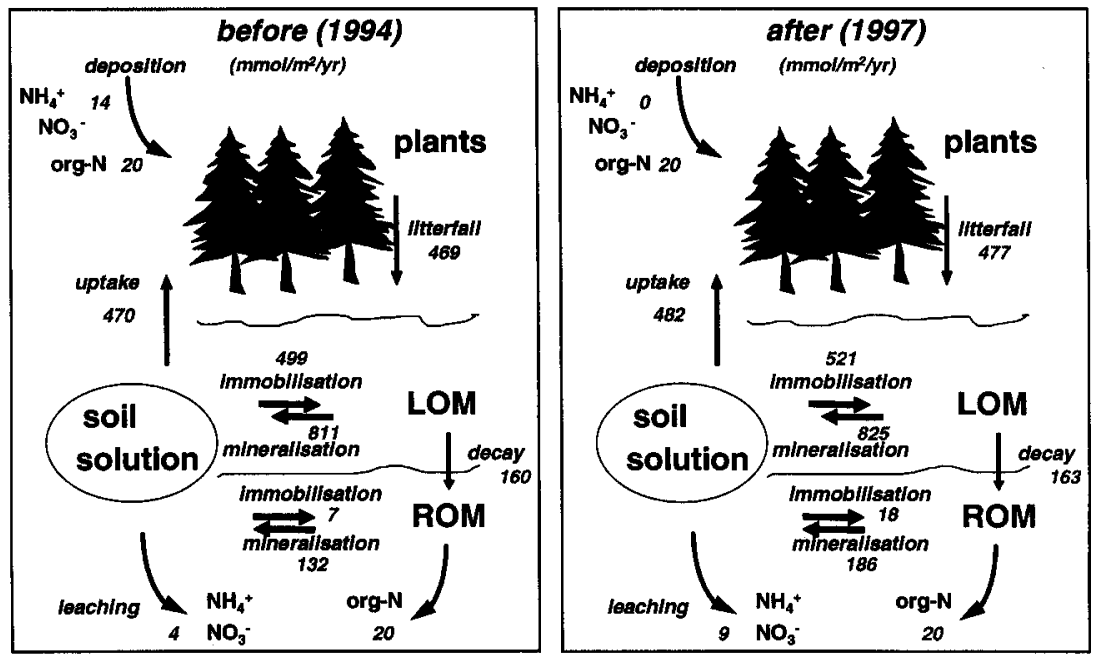

\section{N budgets EGIL catchment}
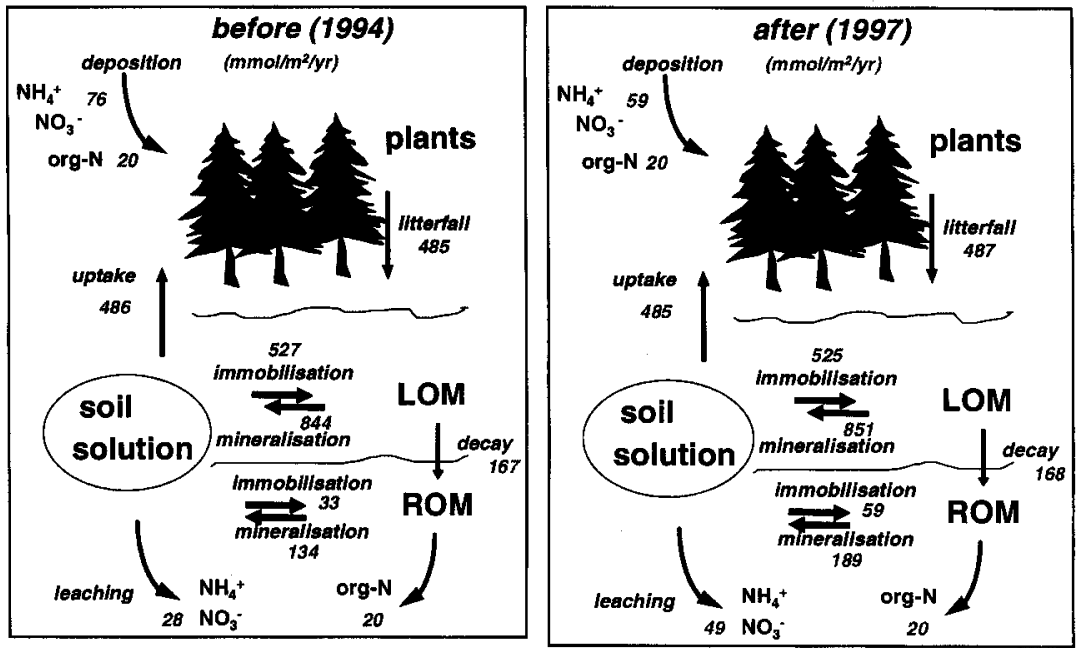

\section{C budgets}
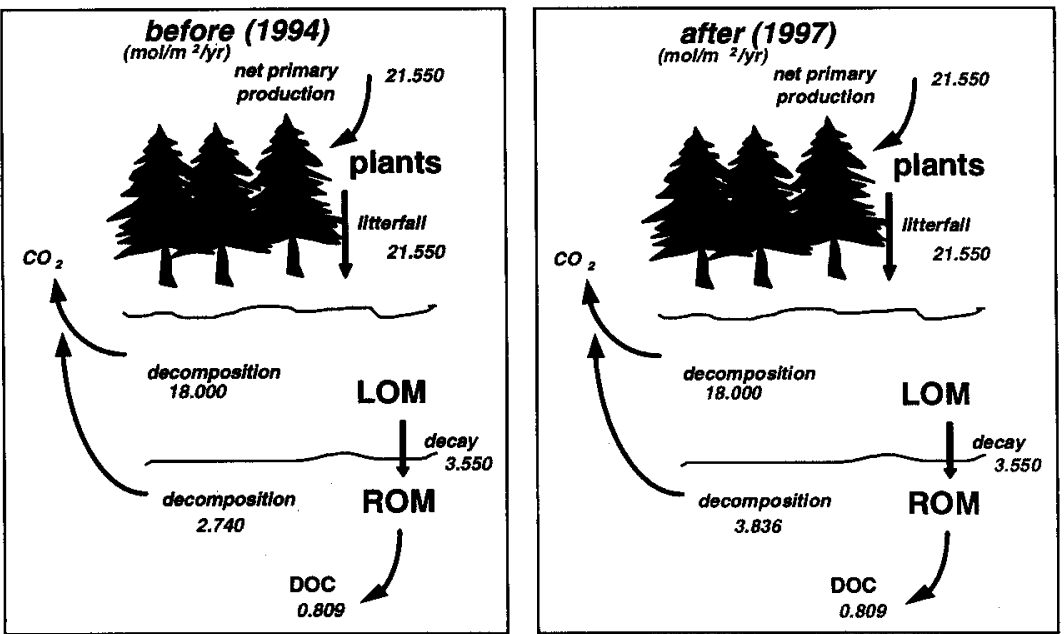

19. 5. $N$ and $C$ cycles at Risdalsheia for the years 1994 (pre-treatment) and 1997 (year 3 treatment) for EGIL and KIM catchments. $C$ cycles are the same for both catchments. Units: mmol $\mathrm{N} \mathrm{m}^{-2} \mathrm{yr}^{-1}$ and mol C $m^{-2} y r^{-1}$. 
4. During the 3 years of CLIMEX treatment at EGIL catchment (soil warming), the flux of $\mathrm{N}$ in runoff increased by about $12 \mathrm{mmol} \mathrm{N} \mathrm{m} \mathrm{mr}^{-2}$ relative to the 3-year pre-treatment condition and to the reference catchments (Lükewille and Wright, 1997).

5. During the 3 years of CLIMEX treatment at KIM catchment $\left(\mathrm{CO}_{2}\right.$ and warming), the flux of $\mathrm{N}$ in runoff increased by about $5 \mathrm{mmol} \mathrm{N} \mathrm{m}^{-2} \mathrm{yr}^{-1}$ relative to the 3 -year clean rain period and to runoff from the control section KIM-c (Wright, 1998).

In addition, measurements of plants and soils conducted as part of the CLIMEX project indicate that:

6. At EGIL catchment (soil warming), there has been no change in growth or biomass of shrubs (W. Arp, pers. comm.) or pine trees (Beier and Rasmussen, 1997), no change in $\mathrm{N}$ concentration in shrub foliage (Arp, pers. comm.) but a small increase in $\mathrm{N}$ concentration in pine needles (Beier and Rasmussen, 1997), and a significant $5-25 \%$ increase in net mineralisation of $\mathrm{N}$ in the soil (Verburg et al.).

7. At KIM catchment, there has been a small but significant increase in growth of the major shrubs Calluna vulgaris and Vaccinium myrtillus (Arp and Berendse, 1997) but no change in the $N$ concentration in foliage of the shrubs. There has been no change in tree growth or biomass but an increase in $\mathrm{N}$ concentration in pine needles (Beier and Rasmussen, 1997). And there has been a significant $40-80 \%$ increase in net mineralisation of $N$ in the soil (Verburg and van Breemen, in press).

8. Decomposition rate of fresh litter was not different under the several treatments (Verburg and van Breemen, in review).

\section{CALIBRATION AND APPLICATION OF MERLIN}

MERLIN is calibrated in several steps using the measurements and estimates summarised in Table 3 :

1. The model is calibrated to reconstruct the observed runoff chemistry at EGIL catchment plot in the period 1983-1994. EGIL catchment received recycled ambient precipitation during this period (RAIN project). The calibration started in year 1904, and the period up to year 1934 is used to allow attenuation of artificial transients caused by initial conditions. This calibration basically sets the initial conditions for $\mathrm{C}$ and $\mathrm{N}$ pools in the soil and the competition for $\mathrm{N}$ between plants, LOM, ROM and runoff and determines the model parameters for all subsequent simulations (Table 4).

2. The response to changes in $\mathbf{N}$ deposition is then evaluated by running the calibrated model with the measured reduced $\mathrm{N}$ deposition from KIM catchment during the period 1984-1994 (RAIN project). No other changes are made to the calibrated parameter set. The simulated $\mathrm{N}$ flux in runoff is compared with the observed.
Table 4. Calibrated parameters for MERLIN at Risdalsheia.

Uptake curves

\section{plants}

opt C/N (strength) $\quad 50$

reference $\mathrm{K} 2 \quad 1000$

reference $\mathrm{C} / \mathrm{N}$ (target) $\quad 42$

$\mathrm{C} / \mathrm{N}$ halfwidth $\mathrm{K} 2 \quad 0.4$

LOM

opt $\mathrm{C} / \mathrm{N}$ (strength) $\quad 20$

reference $\mathrm{K} 2 \quad 1000$

reference $\mathrm{C} / \mathrm{N}$ (target) $\quad 20$

$\mathrm{C} / \mathrm{N}$ halfwidth $\mathrm{K} 2$

ROM

opt C/N (strength) 15

reference $\mathrm{K} 2 \quad 1000$

reference $\mathrm{C} / \mathrm{N}$ (target) $\quad 18.6$

$\mathrm{C} / \mathrm{N}$ halfwidth K2 0.8

nitrification rate $\left(\mathrm{yr}^{-1}\right) \quad 500$

\begin{tabular}{lrcc}
\hline Initial pools $\left(\mathbf{m o l ~ m}^{-2}\right)$ & $\mathbf{C}$ & $\mathbf{N}$ & $\mathbf{C} / \mathbf{N}$ \\
\hline plants & 49 & 1 & 49.0 \\
LOM & 45 & 1.5 & 30.0 \\
ROM & 698 & 32.1 & 21.7 \\
\hline
\end{tabular}

3. The response to soil warming (without $\mathrm{CO}_{2}$ increase) with ambient $\mathrm{N}$ deposition is evaluated by running the calibrated model with changed rates of decomposition and comparing the simulated and observed $\mathrm{N}$ flux in runoff at EGIL catchment during the period 1995-97 (CLIMEX project).

4. The response to increased $\mathrm{CO}_{2}$ and temperature with reduced $\mathrm{N}$ deposition is evaluated by running the calibrated model now with the changes in decomposition rates and comparing the simulated with observed $\mathrm{N}$ flux in runoff from KIM catchment (KIM-t) during the period 1995-97 (CLIMEX project). Again, the parameter set calibrated at EGIL is used directly at KIM changing only the $\mathrm{N}$ deposition according to the measured annual inputs.

The decomposition rate of soil organic matter is temperature dependent (Stanford et al., 1973; Edwards, 1975; Kirschbaum, 1995). In general, increased mineralisation is likely to influence both the ROM and the LOM pool, but measurements at Risdalsheia by Verburg and van Breemen (in review) indicate that fresh litter does not decompose faster at elevated temperatures and, therefore, probably increased decomposition of 'old' organic matter accounts for the observed increase in $\mathrm{N}$ mineralisation at both EGIL and KIM catchments. Increased decomposition rate 
Table 5a. $N$ pools in plants, LOM and ROM at EGIL and KIM catchments modelled for 1934 (prior to onset of N deposition) and 1984 (start of RAIN project), measured in 1994 (start of CLIMEX project) and predicted for year 2004 (10th year of CLIMEX treatment). Also given are total $N$ deposition and runoff fluxes summed over the periods. Units: $\operatorname{mol} \mathrm{N} \mathrm{m}^{-2}$.

\begin{tabular}{lcccccc}
\hline & \multicolumn{2}{c}{ pre-treatment } & \multicolumn{2}{c}{ EGIL } & \multicolumn{2}{c}{ KIM } \\
\hline & 1934 & 1984 & 1994 & 2004 & 1994 & 2004 \\
plants & 1.00 & 1.11 & 1.10 & 1.11 & 1.08 & 1.09 \\
LOM & 1.89 & 2.12 & 2.11 & 2.14 & 2.04 & 2.08 \\
ROM & 31.90 & 33.64 & 34.13 & 34.35 & 33.83 & 33.59 \\
& & & & & $1985-94$ & $1995-04$ \\
deposition & & $1934-84$ & $1985-94$ & $1995-04$ & 0.18 & 0.00 \\
runoff & 3.09 & 0.86 & 1.15 & 0.10 & 0.17 \\
\hline
\end{tabular}

Table 5b. Annual increments for key years in $N$ pools of plants, LOM and ROM and for the ecosystem as modelled by MERLIN for the hindcast (Risdalsheia), EGIL and KIM catchments with and without parming. Units: mmol $\mathrm{N} \mathrm{m}^{-2} \mathrm{yr}^{-1}$.

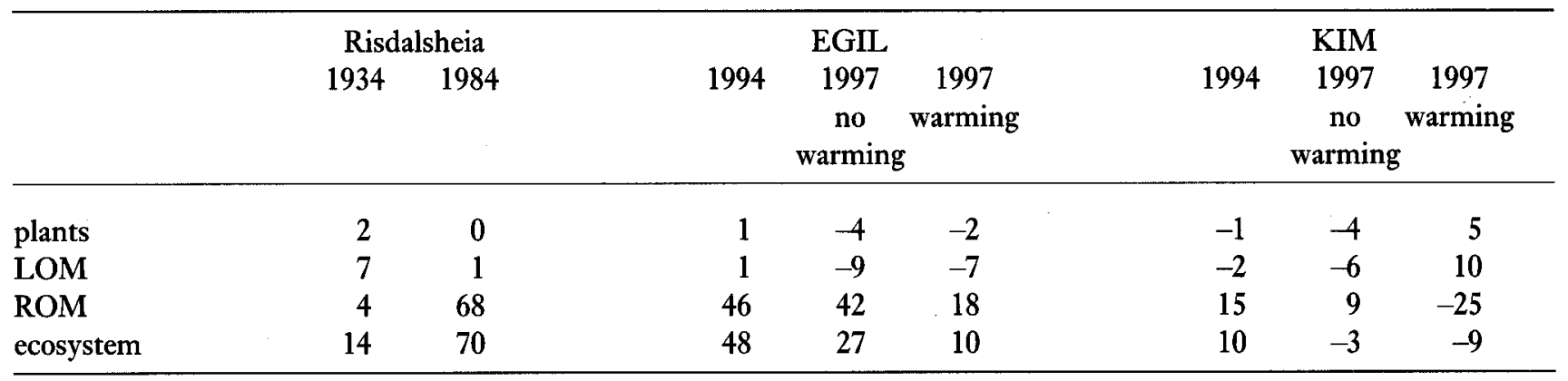

is, therefore, assigned to only the ROM pool. The application of MERLIN aims at estimating how much $\mathrm{C}$ and $\mathrm{N}$ would have to be mineralised to cause the observed $\mathrm{N}$ leaching in EGIL catchment.

\section{Results}

For the hindcast period 1934-84, the calibrated model indicates that of the total $3.1 \mathrm{~mol} \mathrm{~N} \mathrm{~m}^{-2} \mathrm{yr}^{-1}$ input as $\mathrm{N}$ deposition about 0.1 went to plants, 0.2 went to LOM, 1.7

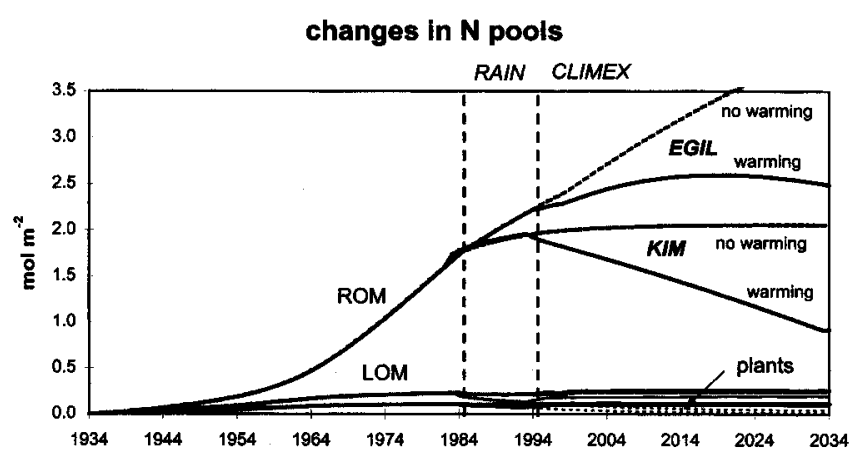

Fig. 6. Changes in $N$ pools in the plant, LOM and ROM compartments simulated by MERLIN over the period 1934 to 2034. went to ROM and 1.0 went to runoff (Fig. 6, Table 5a). Flux of $\mathrm{N}$ in runoff increased from nearly zero in 1934 to about $70 \mathrm{mmol} \mathrm{N} \mathrm{m}^{-2} \mathrm{yr}^{-1}$ in 1984 (Fig. 4).

The model calibration to EGIL catchment for the RAIN project period 1984-1994 fits the general level for the 11 years, but the calibrated values are somewhat lower than those observed during the first half of the period and somewhat higher during the second half (Fig. 7). The choice is either to match the starting value in 1984 and then overshoot the value for 1994 or to match 1994 and undershoot 1984. The latter was selected such that the subsequent effect of the CLIMEX treatment could be best evaluated. Only a small change in the uptake curve for nitrogen in LOM was required to adjust the fit to 1994 rather than 1984 .

When the model calibration from the EGIL plot was run with the measured deposition fluxes for the clean rain catchment KIM, MERLIN predicted the observed values of inorganic nitrogen in runoff satisfactorily during the 11year RAIN project period (Fig. 7).

For the CLIMEX treatments, the model simulates the observed increases in flux at both EGIL and KIM satisfactorily for the 3 years prior to CLIMEX (1992-94) and the 3 years of CLIMEX (1995-97) (Figs. 8 and 9). Yearto-year variations for the 3 years are not well explained. 


\section{EGIL 1984-1994}

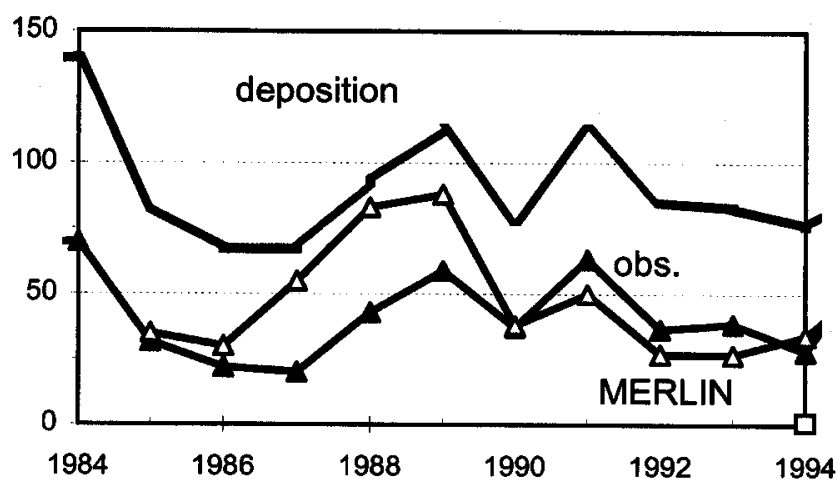

KIM 1984-1994

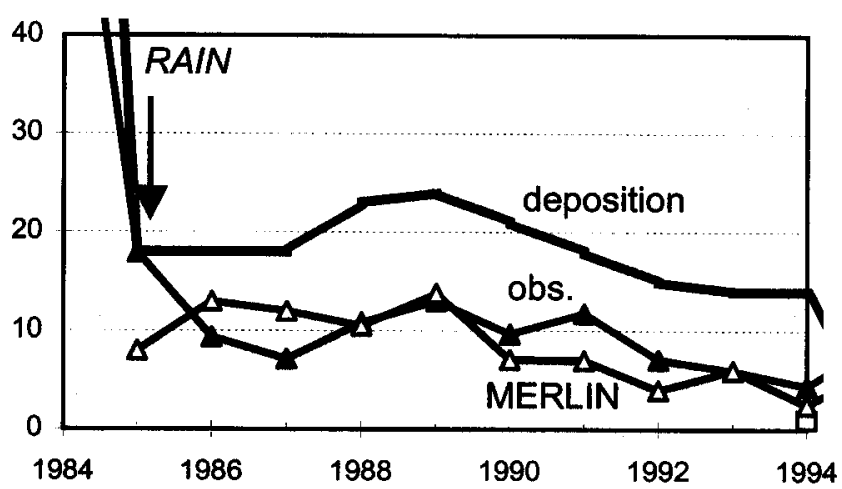

Fig. 7. Deposition and runoff of inorganic nitrogen ( $m m o l m^{-2} \mathrm{yr}^{-1}$ ) from EGIL (acid rain) and KIM (clean rain) catchments measured (open triangles) and modelled by MERLIN (solid triangles) for the RAIN project period 1984-1994. Note the different scales for EGIL and KIM. Data from Wright et al. (1993) and Wright (1998).

The picture is complicated by yearly variations in $\mathrm{N}$ deposition at EGIL and the step decrease in $\mathrm{N}$ deposition at KIM in 1995. Running MERLIN with observed annual N deposition with and without changed decomposition rates, gives an estimate of the amount of change in $\mathrm{N}$ flux in runoff due to variations in deposition and to CLIMEX treatments, respectively. At EGIL, catchment measurements show the 3 year mean value of $\mathrm{N}$ flux increased from pre-treatment of $29 \mathrm{mmol} \mathrm{m}^{-2} \mathrm{yr}^{-1}$ to $47 \mathrm{mmol} \mathrm{m}^{-2}$ $\mathrm{yr}^{-1}$ (Table 6). MERLIN indicates that of the $18 \mathrm{mmol}$ $\mathrm{m}^{-2} \mathrm{yr}^{-1}$ increase, 7 is due to increased $\mathrm{N}$ deposition and the remaining 11 is due to soil warming. Similarly at KIM catchment, for the 3 years prior and the 3 years post treatment, the observed increase in $\mathrm{N}$ flux was $5 \mathrm{mmol} \mathrm{m}^{-2}$ $\mathrm{yr}^{-1}$, while $\mathrm{N}$ deposition decreased by $14 \mathrm{mmol} \mathrm{m}^{-2} \mathrm{yr}^{-1}$. MERLIN indicates that $\mathrm{N}$ runoff would have decreased by $2 \mathrm{mmol} \mathrm{m}^{-2} \mathrm{yr}^{-1}$ without warming (Table 6). The estimated increase due to warming at KIM catchment is thus about $7 \mathrm{mmol} \mathrm{m}^{-2} \mathrm{yr}^{-1}$.

The increase in $\mathrm{N}$ flux at both catchments can be simulated by MERLIN with only one change in the calibrated parameter set. An increase in organic matter decomposition rate in $\mathrm{ROM}$ from $2.7 \mathrm{~mol} \mathrm{C} \mathrm{m} \mathrm{yr}^{-1}$ to $3.8 \mathrm{~mol} \mathrm{C}$ $\mathrm{m}^{-2} \mathrm{yr}^{-1}$ gives the desired effect. For the soil as a whole this increase is only $5 \%$.

The simulations indicate that the increased $\mathrm{N}$ flux due to CLIMEX treatments will be sustained for at least 10
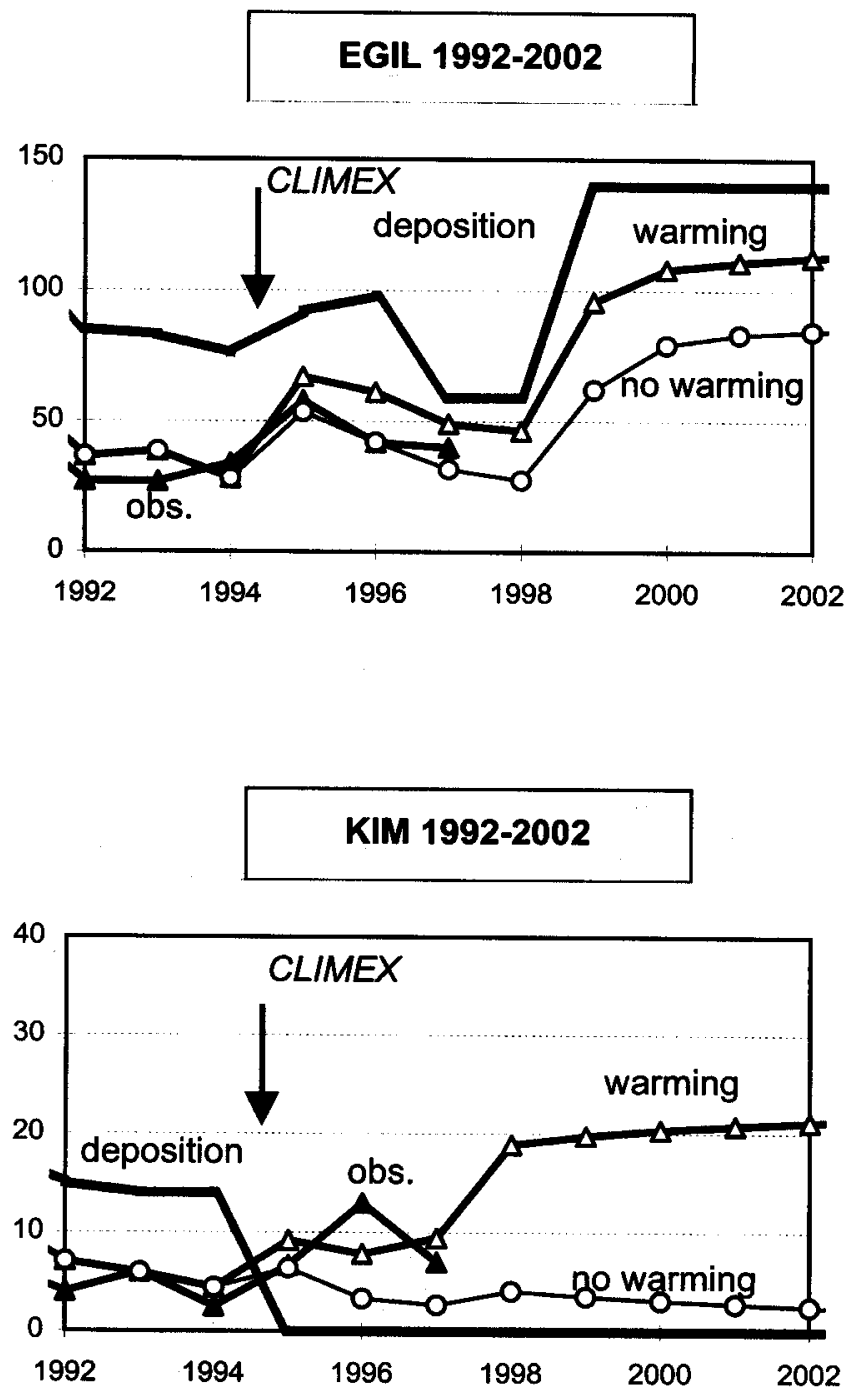

Fig. 8. Deposition and runoff of inorganic nitrogen $\left(\mathrm{mmol} \mathrm{m} \mathrm{m}^{-2} \mathrm{yr}^{-1}\right)$ from EGIL (acid rain, soil warming) and $\mathrm{KIM}$ (clean rain, $\mathrm{CO}_{2}$ and parming) catchments measured (open triangles) and modelled by MERLIN for CLIMEX treatment predicted to the year 2002 (solid triangles). Also shown are MERLIN simulations for no warming (no change in decomposition of ROM) (open circles). Note the different scales for EGIL and KIM. Data from Wright (1998). 
Table 6. Flux of inorganic $N$ in deposition and runoff at EGIL and KIM catchments for 3 years prior- (1992-94) and 3 years treatment (1995-97) measured and simulated by MERLIN, the latter with and without warming. Observed data from Wright (1998). Units: mmol $N$ $m^{-2} y r^{-1}$.

\begin{tabular}{|c|c|c|c|c|c|c|c|c|}
\hline & \multicolumn{3}{|c|}{ EGIL } & \multicolumn{5}{|c|}{ KIM } \\
\hline & DEPOSITION & observed & $\begin{array}{c}\text { RUNOFF } \\
\text { simulated } \\
\text { warming }\end{array}$ & $\begin{array}{c}\text { simulated } \\
\text { no } \\
\text { warming }\end{array}$ & DEPOSITION & observed & $\begin{array}{c}\text { RUNOFF } \\
\text { simulated } \\
\text { warming }\end{array}$ & $\begin{array}{c}\text { simulated } \\
\text { no } \\
\text { warming }\end{array}$ \\
\hline 1992 & 85 & 27 & 30 & & 15 & 4 & 4 & \\
\hline 1993 & 83 & 27 & 32 & & 14 & 6 & 4 & \\
\hline 1994 & 76 & 34 & 23 & & 14 & 2 & 3 & \\
\hline mean & 81 & 29 & 28 & & 14 & 4 & 4 & \\
\hline 1995 & 82 & 58 & 55 & 44 & 0 & 7 & 6 & 4 \\
\hline 1996 & 98 & 42 & 51 & 36 & 0 & 14 & 6 & 2 \\
\hline 1997 & 59 & 40 & 39 & 26 & 0 & 7 & 8 & 1 \\
\hline mean & 80 & 47 & 48 & 35 & $\mathbf{0}$ & 9 & 7 & 2 \\
\hline
\end{tabular}

years at both catchments. The slight jump in $\mathrm{N}$ flux in runoff at KIM catchment simulated for year 4 (1998) is due to the slightly higher volume of runoff used in the predictions for years without measurements.

\section{EGIL catchment}

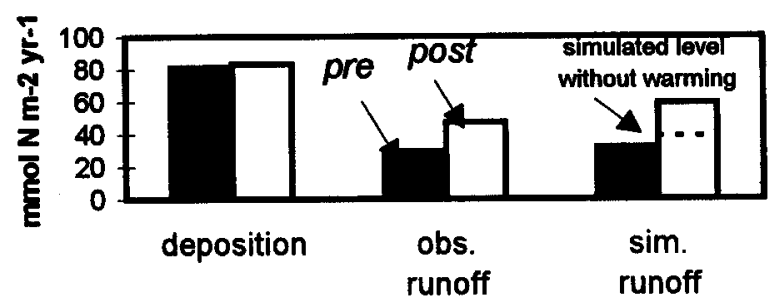

KIM catchment

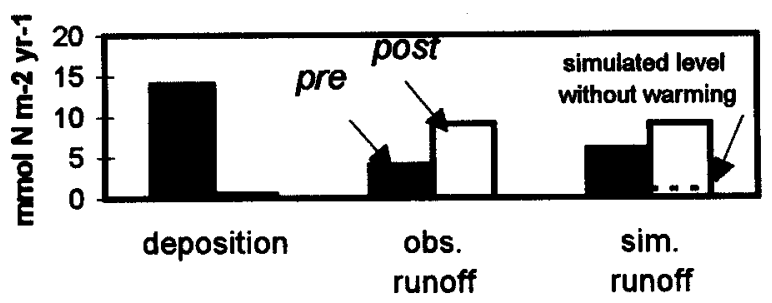

Fig. 9. Mean flux of deposition and runoff of inorganic $N$ for 3 years pre-and 3 years post CLIMEX treatment at EGIL and KIM catchments as measured and simulated by MERLIN. Also shown is the runoff flux simulated with no increase in decomposition by warming (dotted line). Data from Wright (1998).

\section{Discussion}

The changes in $\mathrm{N}$ flux in runoff due to changes in $\mathrm{N}$ deposition at Risdalsheia are well-simulated by MERLIN. The model indicates that the ecosystem accumulates $\mathrm{N}$ over the 50 years of increasing $\mathrm{N}$ deposition, and that most of the $\mathrm{N}$ is retained in the soil. The system begins to leak a larger and larger fraction of the incoming $\mathrm{N}$ as the $\mathrm{C} / \mathrm{N}$ molar ratio in LOM decreases below about 23 (Fig. 10). This is in agreement with the empirical relationships from the ECOFEE data from 65 forest ecosystems in Europe (Gundersen, 1995), and with the experiments of the NITREX project (Gundersen et al., 1998). At Risdalsheia, when the $\mathrm{N}$ deposition is excluded by the roof at KIM catchment in 1984, the system stops leaking $\mathrm{N}$, but still is full of $\mathbf{N}$.

The change in mineralisation rate is probably the most important change caused by the CLIMEX treatments. The temperature-dependence of soil organic matter decomposition is well-known (Kirschbaum, 1995). From the empirical relationships of Kirschbaum (1995), the increase in temperature at $\mathrm{KIM}$ and EGIL of about $3.5^{\circ} \mathrm{C}$, should increase the decomposition rate by about $50 \%$. Laboratory experiments and field measurements at both KIM catchment (Verburg and van Breemen, in review) and EGIL catchment (Verburg et al., in review) indicate that net mineralisation is in the range $330-430 \mathrm{mmol} \mathrm{N}$ $\mathrm{yr}^{-1}$ per $\mathrm{m}^{-2}$ soil (Fig. 11). The measured increase at KIM for the first 2 years of treatment is about $170 \mathrm{mmol} \mathrm{N} \mathrm{yr}^{-1}$ per $\mathrm{m}^{-2}$ soil.

Extrapolated to the whole KIM catchment with $50 \%$ soil cover and only $80 \%$ of the drainage area subjected to the warming, the measured increase in net mineralisation is $70 \mathrm{mmol} \mathrm{m} \mathrm{yr}^{-1}$. MERLIN gives $50 \mathrm{mmol} \mathrm{m}^{-2} \mathrm{yr}^{-1}$. Although the simulated values agree well with measured 


\section{$\mathrm{C} / \mathrm{N}$ ratios plants}
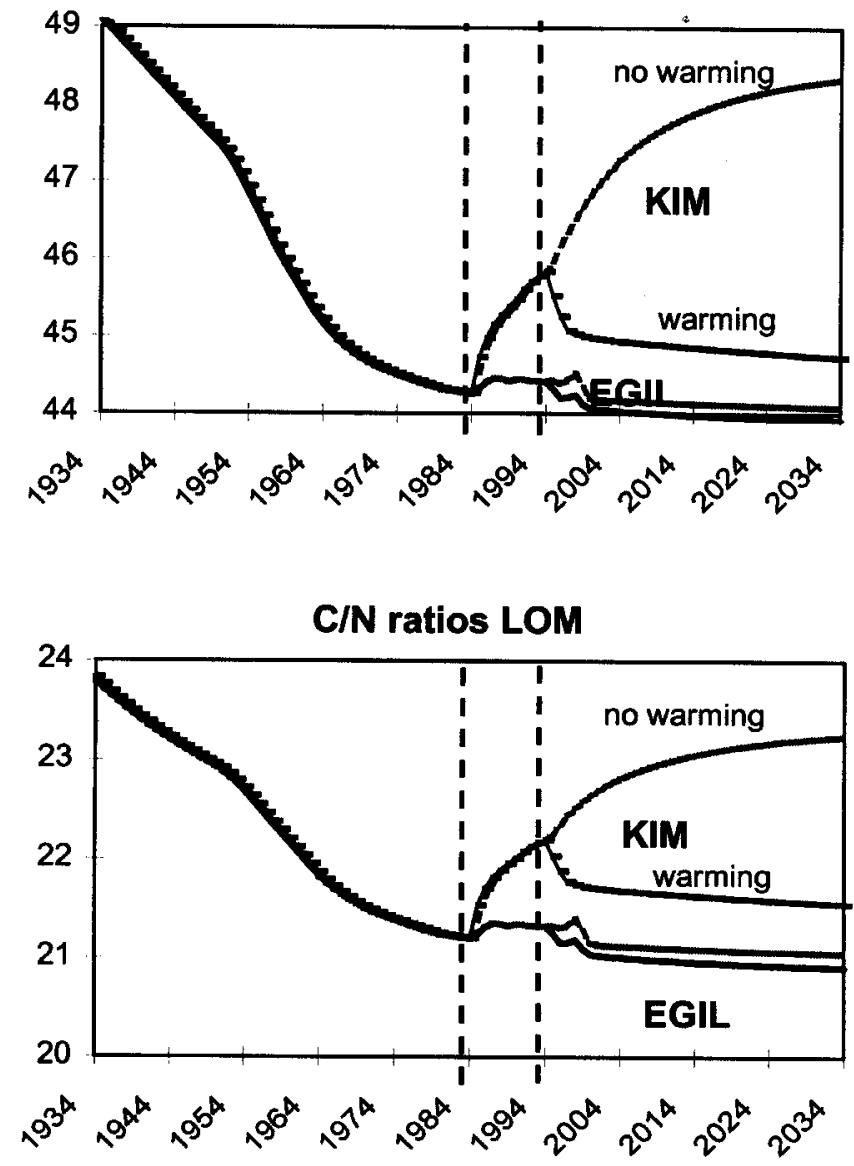

C/N ratios ROM

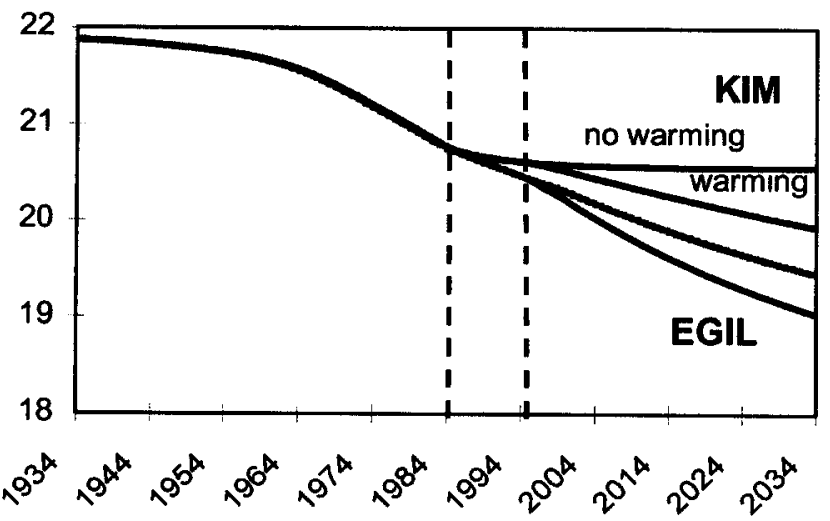

Fig. 10. Molar $C / N$ ratios in plant, LOM and ROM compartments simulated by MERLIN over the period 1934-2034.

change in net mineralisation, the absolute levels are quite different; measurements are about $160 \mathrm{mmol} \mathrm{m} \mathrm{m}^{-2}$, while simulated values are $420 \mathrm{mmol} \mathrm{m}^{-2} \mathrm{yr}^{-1}$.

The higher simulated values are necessitated by the estimate for litterfall at $480 \mathrm{mmol} \mathrm{m}^{-2} \mathrm{yr}^{-1}$. This estimate includes fine-root turnover. Closure of the ecosystem $\mathrm{N}$ cycle requires that $\mathrm{N}$ in litterfall must either mineralise or accumulate in LOM or ROM. The rate of litterfall at
Risdalsheia is quite uncertain; measurements include only above-ground litter from trees, and both litter from shrubs and ground vegetation as well as fine-root turnover are rough estimates. The litterfall used to construct the $\mathrm{N}$ cycle is thus quite uncertain, and consequently the absolute value of net mineralisation simulated by MERLIN is also quite uncertain.

The change in net mineralisation, however, is tightly constrained by the observed changes in $\mathrm{N}$ flux in runoff. and here the measured and simulated changes in net mineralisation agree quite well. The MERLIN simulation required an increase in soil organic matter decomposition (gross mineralisation) of only $5 \%$ to obtain the observed increase in $\mathrm{N}$ flux in runoff. At EGIL catchment, drying of the soils caused by the heating cables may limit the increase of mineralisation. This would tend to reduce the increase in mineralisation rate due to the increase temperature at EGIL relative to KIM. The model indicates that about $50 \%$ of the extra $\mathrm{N}$ released by the increased decomposition of ROM is immobilised again in ROM and the rest is lost, mostly to runoff. The increased decomposition of ROM otherwise gives only minor changes in gross and net mineralisation and uptake in the other compartments.

MERLIN indicates that, in 1984 when N input to KIM was reduced, there were minor reallocations of $N$ within the ecosystem (Fig. 6, Table 5b). Before heating, the N pool in LOM at KIM was slightly depleted each year and $\mathrm{N}$ transferred to ROM, whereas at EGIL the $\mathrm{N}$ pool in LOM was not changing (Table 5b). When the CLIMEX treatments began in April 1994 (year 1995) decomposition of ROM increased dramatically and almost equally in KIM and EGIL catchments. However, the increased $\mathrm{N}$ was allocated differently. At KIM, the new $\mathrm{N}$ available changes the plant and LOM compartments to be net sinks of $\mathrm{N}$ in

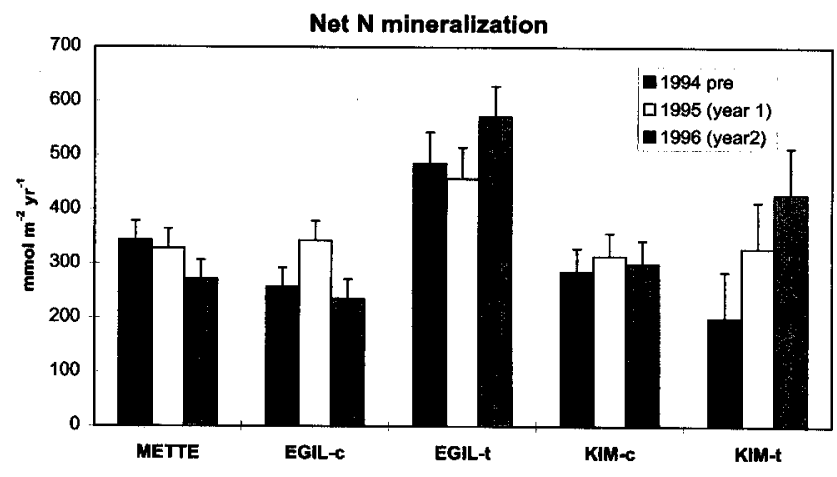

Fig. 11. Mean and standard error of 10 replicate measurements of net mineralisation of nitrogen in soil at Risdalsheia as determined by the sequential soil core incubation method. Sites are: METTE (untreated reference catchment), EGIL-c (control section of EGIL), EGIL-t (treatment section of EGIL), KIM-c (control section of $K I M$ ) and KIM-t (treatment section of KIM). Units: $\mathrm{mmol} \mathrm{m^{-2 }}$ $y^{-1}$ of soil. The catchments have about $50 \%$ soil cover. Data from Verburg and van Breemen (in reviem) and Verburg et al. (in reviem). 
that a fraction of the $\mathrm{N}$ mineralised in ROM is transferred to LOM and to plants. In EGIL, neither plant nor LOM $\mathrm{N}$ pools change very much; instead almost $50 \%$ of the mineralised $\mathrm{N}$ from ROM is re-immobilised in ROM. The difference between KIM and EGIL is a consequence of the 11-year difference in $\mathrm{N}$ input; this means that the effect of global warming on N-leaching will be strongly dependent on the $\mathrm{N}$ deposition prior to and during the climate change.

Measurements have shown that the $\mathrm{N}$ status in pine needles at KIM-t has increased from $1.6 \mathrm{mgN} \mathrm{g}^{-1}$ to about $1.9 \mathrm{mgN} \mathrm{g}^{-1}$ (Fig. 12) (Beier and Rasmussen, 1997). This level is comparable to outside the roof where $\mathrm{N}$ addition has not been reduced during the 14 years of experiment. MERLIN does not model the needle $\mathrm{N}$ content specifically but the model results show a significant increase in $\mathbf{N}$ pool (decrease in $\mathrm{C} / \mathrm{N}$ ratio) in the total active plant biomass to the same level as prior to the RAIN and CLIMEX experiments (Fig. 10). The change in allocation of nitrogen to plants following changes in $\mathrm{N}$ availability, however, is smaller for the model prediction compared to the measurements. The reduced $\mathrm{N}$ input during the RAIN project reduced needle $\mathrm{N}$ by $15-20 \%$ which equals a change in total plant $\mathrm{N}$ of about $3-4 \%$. The nitrogen status in the foliage recovers almost completely as the $\mathrm{N}$ availability increases by the warming and returns to the level observed in the control plot outside the roof. The drop and return in plant $\mathrm{N}$ in KIM-t following the treatments are well predicted by MERLIN, but the drop in plant $\mathrm{N}$ predicted by the model is only in the order of $1 \%$.

A potential impact of the increased $\mathrm{CO}_{2}$ and temperature in KIM-t might be increased biomass growth compared to the increased temperature alone in EGIL. The measurements on ground vegetation have not shown any changes in growth, and the three years of treatments are insufficient to detect changes in tree growth. There is no room in the model for increased $\mathrm{N}$ uptake by plants at KIM due to increased growth and biomass accumulation. This would necessitate even larger increases in mineralisa-

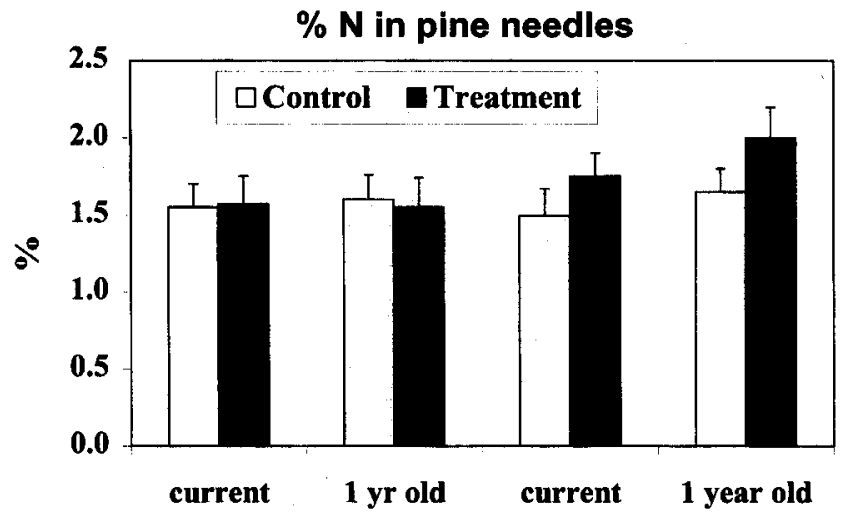

Fig. 12. $\% N$ in Pinus sylvestris needles collected before treatment and year 3 treatment (1997) at KIM catchment (data from Beier and Rasmussen, 1997). tion rate from ROM to supply the N necessary, and would make less $\mathrm{N}$ available to runoff. Different percent changes in decomposition rates would then be needed for the EGIL and KIM catchments. The available data are insufficient to justify setting increased growth rates in KIM-t or to set different rates of decomposition at EGIL and KIM catchments.

The modelled $5 \%$ increase in rate of decomposition of soil organic matter amounts to an annual loss of carbon in ROM of only $1.1 \mathrm{~mol} \mathrm{~m}^{-2} \mathrm{yr}^{-1}$ of the total ROM pool of $700 \mathrm{~mol} \mathrm{~m}^{-2}$, i.e. $0.16 \%$ per year. There is sufficient $\mathrm{C}$ stock to allow this depletion to go on for decades. It is unknown, however, how much of the total $\mathrm{C}$ pool in the soil is susceptible to increased decomposition at elevated temperature. Furthermore, it is not known whether the new litterfall formed at higher $\mathrm{CO}_{2}$ levels will decompose at the same rate as litter formed at ambient $\mathrm{CO}_{2}$ levels. Clearly, additional years of CLIMEX treatment are critically needed to test the persistence of the increased decomposition and mineralisation of $\mathrm{N}$.

The choice of CLIMEX experiment at the KIM catchment turns out to be very fortuitous. The system was poised prior to the start of the CLIMEX treatments; decades of $\mathrm{N}$ deposition had loaded the system with $\mathrm{N}$, but the exclusion of $\mathrm{N}$ deposition in 1984 at the onset of the RAIN project, resulted in very little $\mathrm{N}$ deposition and very little $\mathrm{N}$ flux in runoff over the next 11 years. The relatively small changes in $\mathrm{N}$ cycling processes caused by CLIMEX beginning in 1994, thus, were readily manifest by significant change in $\mathrm{N}$ flux in runoff. The runoff signal is very sensitive and strong, whereas the changes in the internal processes are relatively small and difficult to measure directly. Given the natural heterogeneity and operational uncertainties in the techniques, detection of a $5 \%$ change in soil organic matter decomposition rate in the field and integrated over a whole catchment is a nearly impossible task.

The uncertainties in measurements of $\mathrm{N}$ processes within the ecosystem are so large that they do not constrain the model adequately. It is difficult, for example, to estimate a whole-ecosystem value for increase in growth and biomass due to CLIMEX. Not all species showed a significant change; for example, Calluna increased, but Vaccinium did not (Arp and Berendse, 1997). Litterfall from ground species is difficult to measure, and fine-root turnover is not measured at all. Uncertainties in net mineralisation rate are $\pm 25 \%$ (Verburg and van Breemen, in review). Thus the structure of MERLIN cannot be rejected on the basis of the data available from CLIMEX.

MERLIN accounts, adequately, for nearly all of the observed changes at Risdalsheia over the entire 13-year period and the 2 superimposed treatments. One calibrated model explains the observed changes in $\mathrm{N}$ flux in runoff following first a drastic reduction in $\mathrm{N}$ deposition and then changed temperature and $\mathrm{CO}_{2}$. Additional years of CLIMEX treatment are needed to test the robustness of the model. 


\section{Acknowledgements}

This work has been supported in part by the Commission of European Communities (DYNAMO ENV4-CT95-0030), the Research Council of Norway, the Norwegian Institute for Water Research, and Risø National Laboratory, Denmark.

\section{References}

Arp, W. and Berendse, F., 1997. Effects on dwarf shrub vegetation. In: CLIMEX project: Results from the Third Year of Treatment (A. Jenkins (Ed)). Climate Change Research Report 9/1997, 28-35. Norwegian Institute for Water Research, Oslo.

Aber, J.D., Nadelhofer, K.J., Streudler P. and Melillo, J., 1989. Nitrogen saturation in northern forest ecosystems. BioScience, 39, 378-386.

Beier, C. and Rasmussen, L., 1997. Tree responses, p. 36-44, In: CLIMEX project: Results from the Third Year of Treatment (A. Jenkins (Ed)). Climate Change Research Report 9/1997, 36-44. Norwegian Institute for Water Research, Oslo.

Cosby, B.J., Ferrier R.C., Jenkins, A., Emmett, B.A., Wright, R.F. and Tietema, A., 1997. Modelling the ecosystem effects of nitrogen deposition at the catchment scale: model of ecosystem retention and loss of inorganic nitrogen (MERLIN). Hydrol. Earth System Sci., 1, 137-158.

Dise, N.B. and Jenkins, A. (Eds.) 1995. The CLIMEX Project: Whole Catchment Manipulation of $\mathrm{CO}_{2}$ and Temperature. Climate Change Research Report 3/95, Norwegian Institute for Water Research, Oslo, $130 \mathrm{pp}$.

Edwards, N.T., 1975. Effects of temperature and moisture on carbon dioxide evolution in a mixed deciduous forest floor, Soil Sci. Soc. Am. Proc., 39, 361-365.

Emmett, B.A., Cosby B.J., Ferrier, R.C., Jenkins, A., Tietema, A. and Wright, R.F., 1997. Modelling the ecosystem effects of nitrogen deposition at the catchment scale: simulation of nitrogen saturation in a Sitka spruce forest, Aber, Wales, UK. Biogeochemistry, 38, 129-148.

Fischer, D.C. and Oppenheimer, M., 1991. Atmospheric nitrogen deposition and the Chesapeake Bay estuary. Ambio, 20, 102-108.

Gundersen, P., 1995. Nitrogen deposition and leaching in European forests-preliminary results from a data compilation. Water Air Soil Pollut., 85, 1179-1184.

Gundersen, P., Emmett, B.A., Kjønaas, O.J., Koopmanns, C.J. and Tietema, A., 1998. Impact of nitrogen deposition on nitrogen cycling in forests: a synthesis of NITREX data. Forest Ecol. Manage., 101, 37-56.

Henriksen, A. and Brakke, D.F., 1988. Increasing contributions of nitrogen to the acidity of surface waters in Norway. Water Air Soil Pollut., 42, 183-201.

Kauppi, P.E., Mielikäinen, K. and Kuusela, K., 1992. Biomass and carbon budget of European forests, 1700 to 1990 . Science, 256, 70-72.

Kjønaas, O.J., Wright, R.F. and Cosby, B.J., 1997. MERLIN model applied to NITREX Gairdsjön. Acid Rain Research Report 46/1997, Norwegian Institute for Water Research, Oslo, 38 pp.

Kirschbaum, M.U.F., 1993. A modelling study of the effects of changes in atmospheric $\mathrm{CO}_{2}$ concentration, temperature and atmospheric nitrogen input on soil organic carbon storage. Tellus, 45B, 321-334.
Kirschbaum, M.U.F., 1995. The temperature dependence of soil organic matter decomposition, and the effect of global warming on soil organic C storage. Soil Biol. Biochem., 27, 753-760.

Kirschbaum, M.U.F. and Fischlin, A. (Eds.) 1995. Climate change impacts on forests. In: Climate Change 1995. Impacts, Adaptations and Mitigation of Climate Change: ScientificTechnical Analyses. Contributions of Working Group II to the Second Assessment Report of the Intergovernmental Panel on Climate Change, 95-129. Cambridge University Press, Cambridge.

Lajtha, K., Seely, B. and Valiela, I., 1995. Retention and leaching losses of atmospherically-dervied nitrogen in the aggrading coastal watershed of Waquoit Bay, MA. Biogeochemistry, 28, $33-54$.

Lükewille, A., Arp, W., Verburg, P., Jenkins, A. and Wright, R.F., 1995. The CLIMEX soil heating experiment at Risdalsheia, Southern Norway. In: Ecosystem Manipulation Experiments: Scientific Approaches, Experimental Design, and Relevant Results. (Jenkins, A., Ferrier, R.C. and Kirby, C. (Eds)), 331-334. Ecosystem Research Report 20. Commission of the European Communities, Brussels.

Lükewille, A. and Wright, R.F., 1997. Experimentally increased soil temperature causes release of nitrogen at a boreal forest catchment in southern Norway. Global Change Biology, 3, 13-21.

Melillo, J.M., McGuire, A.D., Kicklighter, D.W., Moore, B. III, Vorosmarty, C.J. and Schloss, A.L., 1993. Global climate change and terrestrial net primary production. Nature, Lond. $363,234-240$.

Persson, H., 1990. Structural properties of the field and bottom layers at Ivantjärnsheden. Ecol. Bull. (Stockholm), 32, 153-163.

Rastetter, E.B., Ryan, M.G., Shaver, G.R., Melillo, J.M., Nadelhoffer, K.J., Hobbie. J.E. and Aber, J.D., 1991. A general biogeochemical model describing the responses of the $\mathrm{C}$ and $\mathrm{N}$ cycles in terrestrial ecosystems to changes in $\mathrm{CO}_{2}$, climate and $\mathrm{N}$ deposition. Tree Physiology, 9, 101-126.

Schindler, D.W. and Bayley, S.E., 1993. The biosphere as an increasing sink for atmospheric carbon: estimates from increasing nitrogen deposition. Global Biogeochemical Cycles, 7, 717-734.

Simpson, D., Olendrzynski, K., Semb, A., Støren, E. and Unger, S. 1997. Photochemical oxidant modelling in Europe: multiannual modelling and source-receptor relationships. EMEP/MSC-W Report 3/97, Norwegian Meteorological Institute, Oslo, Norway, $75 \mathrm{pp}$.

Stanford, G., Frere, M. and Schwaninger, D.E., 1973. Temperature coefficient of soil nitrogen mineralisation. Soil Sci., 115, 321-323.

Van Breemen, N., Jenkins, A., Wright, R.F., Arp, W.J., Beerling, D.J., Berendse, F., Beier, C., Collins, R., van Dam, D., Rasmussen, L., Verburg, P.S.J. and Wills, M.A., 1998. Impacts of elevated carbon dioxide and temperature on a boreal forest ecosystem (CLIMEX project). Ecosystems, 1, 345-351.

Verburg, P.S.J., Van Loon, W.K.P. and Lükewille, A., (in press). The CLIMEX soil-heating experiment: soil response after 2 years of treatment. Biol. Fertility Soils.

Verburg, P.S.J. and van Breemen, N. Experimental manipulation of a forested catchment: litter decomposition and $\mathrm{N}$ mineralisation. Biogeochemistry, (in press). 
Wright, R.F., 1998. Effect of increased $\mathrm{CO}_{2}$ and temperature on runoff chemistry at a forested catchment in southern Norway (CLIMEX project). Ecosystems, 1, 216-225.
Wright, R.F., Lotse, E. and Semb, A., 1993. RAIN project: results after 8 years of experimentally reduced acid deposition to a whole catchment. Can. F. Fish. Aquat. Sci., 50, 258-268. 